\title{
Gene Mutations in Lymphoproliferative Disorders of T and NK/T Cell Phenotypes Developing in Renal Transplant Patients
}

\author{
Yoshihiko Hoshida, Tadashi Hongyo, Shin-ichi Nakatsuka, Mieko Nishiu, \\ Tetsuya Takakuwa, Yasuhiko Tomita, Taisei Nomura, and Katsuyuki Aozasa \\ Departments of Pathology (YH, SN, MN, TT, YT, KA) and Radiation Biology (TH, TN), Osaka University Medical \\ School, Osaka, Japan
}

\begin{abstract}
SUMMARY: Post-transplantation lymphoproliferative disorder (PT-LPD) is characterized by lymphoid proliferation after organ or bone marrow transplantation. In Western countries, most cases of PT-LPD are B-cell-derived and Epstein-Barr virus-associated, in which alterations of $c-m y c, p 53$, and $\mathrm{N}$-ras genes might play a role in disease progression. In Japan, PT-LPD of T- and NK/T-cell types are not uncommon in renal transplant patients. Mutations of $p 53$ (exons 4 through 8), K-ras (exons 1 and 2), c-kit (exons 11 and 17), and $\beta$-catenin genes (exon 3 ) in 12 cases of these diseases were analyzed by PCR single strand conformation polymorphism and then by direct sequencing. $p 53$ gene mutations were detected in 5 of 5 cases of peripheral T-cell lymphoma, $3(60 \%)$ of 5 cases of adult T-cell leukemia/lymphoma, and 1 of 2 cases of NK/T cell lymphoma. Twenty-five percent of T and $\mathrm{NK} / \mathrm{T}$ cell lymphomas showed K-ras mutations. Mutations of $c$-kit and $\beta$-catenin genes were found in $33 \%$ of cases. Among a total of 42 substitution mutations, 40 were transitions with involvement of $\mathrm{CpG}$ sites in 20 to $30 \%$ of cases. Most cases had at least one mutation that changed an amino acid, which might have provided the selection pressure for expansion. These findings suggested that $p 53$ gene mutations might play a central role in development of peripheral T-cell lymphoma including adult T-cell leukemia/lymphoma in renal transplant patients. (Lab Invest 2002, 82:257-264).
\end{abstract}

ost-transplantation lymphoproliferative disorders
(PT-LPD) are characterized by lymphoid proliferation occurring after organ or bone marrow transplantation (Nalesnik, 1998; Pen et al, 1969). Most are B-cell-derived, Epstein-Barr virus-associated, and show poor prognosis. Spontaneous regression of the lesions is occasionally seen when immunosuppressive agents are reduced (Nalesnik, 1998; Starzl et al, 1984). PT-LPD of B-cell type are categorized into four groups: reactive plasmacytic hyperplasia, polymorphic PT-LPD, monomorphic PT-LPD, and others including plasmacytoma-like PT-LPD (Harris et al, 1997). Clinical outcomes of plasmacytic hyperplasia and polymorphic PT-LPD are significantly better than those of monomorphic PT-LPD (Chadburn et al, 1998). Molecular genetic studies of B-cell-type PT-LPD have suggested that alterations of $c-m y c, p 53$, and $\mathrm{N}$-ras genes might play a role in progression of polymorphic PT-LPD to monomorphic PT-LPD (Knowles et al, 1995).

Most PT-LPD cases are B-cell-derived in Western countries (Dockrell et al, 1998; Leblond et al, 1995),

Received September 4, 2001.

This work was supported by grants from the Ministry of Education, Science, and Culture, (10042005, 10151225, 11470353, 11670212, 11680546, 12576004, 12670159, 1277087), Japan.

Address reprint requests to: Dr. Katsuyuki Aozasa, Department of Pathology (C3), Osaka University Medical School, 2-2 Yamadaoka, Suita, Osaka 565-0871, Japan.E-mail: aozasa@molpath.med.osaka-u.ac.jp whereas a recent study revealed that PT-LPD of Tand NK/T-cell type are not uncommon in Japan (Hoshida et al, 2001). Characteristically, half of the T-cell cases are adult T-cell leukemia/lymphoma (ATL) with proven human T-lymphotropic virus type I (HTLV-1) genome in the tumor tissues and seropositivity for HTLV-1. This high frequency of ATL might be caused by transmission of HTLV-1 via blood transfusion during hemodialysis, because Japanese patients usually receive various periods of hemodialysis before renal transplantation (Hoshida et al, 2001). Little information is available regarding the molecular genetic characteristics of PT-LPD of T-cell and NK/T-cell type. In the present study, mutations of $p 53, c-k i t, \mathrm{~K}$-ras, and $\beta$-catenin genes in PT-LPD of T-cell and NK/T-cell type in renal transplant patients were analyzed by PCR single strand conformation polymorphism (PCR-SSCP) and then by direct sequencing.

p53 is a well-known tumor suppressor gene that causes cells with damaged DNA to arrest at the G1 phase of the cell cycle or stimulates the expression of the bax gene encoding a protein that promotes apoptosis (Levine et al, 1991). p53 gene mutations have been detected in a wide variety of human cancers, mainly in exons 5 through 8 (Hollstein et al, 1991). A high incidence of malignant lymphoma in p53 knockout mice has been reported (Donehower et al, 1992), suggesting an important role of $p 53$ gene mutations in lymphomagenesis. 
The c-kit proto-oncogene encodes a receptor tyrosine kinase, which plays a crucial role in proliferation and differentiation of hematopoietic stem cells, mast cells, and interstitial cells of Cajal. Development of acute leukemia or malignant lymphoma was reported in transgenic mice expressing KIT v814 (Asp $814 \rightarrow$ VAL) (Kitayama et al, 1996). Recently, we reported the high frequency of $c$-kit gene mutations in sinonasal NK/T-cell lymphoma (Hongyo et al, 2000).

The K-ras gene encodes 21-KD ras protein, a GTPand GDP-binding protein, which plays a role in signal transduction through transmembrane signaling systems. Mutations of the ras gene, mostly involving codon 12, stabilize ras protein in its GTP-bound active form and cause constitutive signal transduction that might result in malignant transformation of the mutated cells (Barbacid, 1987). Indeed, K-ras mutations are frequently observed in pancreatic, colorectal, and lung adenocarcinoma (Brentnall et al, 1995; Jackson et al, 1997).

The $\beta$-catenin gene is a homolog of the Drosophila Armadillo gene and plays an important role in cell-cell adhesion and signal transduction. $\beta$-catenin links the cytoplasmic domain of E-cadherin to $\alpha$-catenin and anchors this complex to the actin cytoskeleton (Huber et al, 1996). $\beta$-catenin forms heterodimers with DNAbinding proteins, which function as downstream transcriptional activators in the Wnt signaling pathway (Behrens et al, 1996). Without signaling stimulus, $\beta$-catenin is degraded in association with adenomatous polyposis coli (APC) and glycogen synthase kinase $3 \beta$ (GSK3 $\beta$ ) (Aberle et al, 1997). Therefore, either mutations in $A P C$ or activating mutations at crucial regulatory sites in exon 3 of the $\beta$-catenin gene result in accumulation of $\beta$-catenin protein in the cytoplasm (Morin et al, 1997). Then, $\beta$-catenin complex leads to overexpression of c-myc, which is related to cell proliferation and differentiation, thus leading to tumorigenesis ( $\mathrm{He}$ et al, 1998). Indeed, mutations of the $\beta$-catenin gene have occasionally been found in several kinds of cancers (Fukuchi et al, 1998; Hsu et al, 2000; Sparks et al, 1998; Voeller et al, 1998). Although there have been no reports describing mutations of the $\beta$-catenin gene in malignant lymphomas, Knowles et al (1995) reported a crucial role of overexpression of the $c-m y c$ gene in progression from polymorphic to monomorphic PT-LPD of B-cell type. Therefore, we examined $\beta$-catenin gene mutations in T- and NK/T-cell PT-LPD.

\section{Results}

\section{Mutations of p53, c-kit, $K$-ras, and $\beta$-catenin Genes}

By direct sequencing of SSCP products, 24 singlenucleotide substitution mutations in the p53 gene were detected in 9 of 12 cases with T- and NK/T-cell lymphoma (Table 1). p53 gene mutations were found in all cases of peripheral T-cell lymphoma, $60 \%$ of ATL, and $50 \%$ of NK/T-cell lymphomas (Fig. 1). In peripheral T-cell lymphoma, not specified, three cases had three mutations and one case had five mutations.
Mutations were located in exon 5 (12 of 24 cases, $50 \%$ ) and exon 4 (6 of 24 cases, 25\%). Sixteen mutations were missense mutations leading to amino acid substitutions, and eight were silent mutations resulting in no amino acid changes. G:C to $A: T$ transitions were the predominant mutations (16 mutations), followed by A:T to G:C transitions (6 mutations). Two were transversion mutations. Three mutations found at codons 175 (Case 8), 196, and 273 (Case 2) with CpG sites were reported previously as hot spots (Donehower et al, 1992).

In the c-kit gene, seven single-nucleotide substitution mutations were detected in 4 (33.3\%) of 12 cases (Table 2). These were located at exon 11 (six mutations, $85.7 \%$ ) and exon 17 (one mutation, 14.3\%). One mutation was detected in two cases and two and three mutations were detected in one case each. Four mutations were missense and three were silent. Six mutations were $G: C$ to $\mathrm{A}: \mathrm{T}$ transitions and one was an $\mathrm{A}: \mathrm{T}$ to $\mathrm{G}: \mathrm{C}$ transition.

Four mutations were detected in the K-ras gene in three cases: all were $G$ to $A$ transitions. Three of the four were missense mutations. There were three mutations in the $\beta$-catenin gene, and all were $G$ to $A$ transitions.

\section{Discussion}

Most cases of PT-LPD in Western countries are Bcell-derived, and information regarding the genetic mechanism in B-cell PT-LPD has been accumulating. Mutation analysis of the p53 gene has been confined principally to exons 5 through 8 because $90 \%$ of the mutations in human tumors occurred in this region (Hollstein et al, 1991). Monomorphic PT-LPD might have a genetic alteration including $p 53$, whereas polymorphic PT-LPD does not, suggesting that p53 mutations are important for progression of B-cell PT-LPD (Knowles et al, 1995). p53 gene mutations are also frequent in AIDS-related B-cell lymphoma (Gaidano et al, 1998). These findings suggested that p53 mutations are common findings in lymphomas developing in immunocompromised hosts, which are frequently Epstein-Barr virus-associated (Edwards and RaabTraub, 1994).

All of the cases in our study that had peripheral T-cell lymphoma other than ATL showed p53 mutations, which is a striking contrast to that in T-cell lymphoma developed in immunocompetent individuals (8.3\%; $p<0.01$; Fisher's exact test) (Gaidano et al, 1998). Imamura et al (1994) reported that approximately $30 \%$ to $50 \%$ of ATL showed p53 mutations and suggested that $p 53$ gene mutations play a role in the late stage of tumorigenesis; that is, evolution from a polyclonally or oligoclonally expanded population of cells to monoclonal expansion might result from p53 gene mutations. The frequency of $p 53$ mutations in the patients in our study who had ATL was $60 \%$, which was similar to that in ATL in immunocompetent individuals. A case of nasal NK/T-cell lymphoma showed p53 mutations. We recently reported the relatively high frequency of $p 53$ mutations in cases of nasal NK/Tcell lymphoma (Li et al, 2000). 
Table 1. p53 Gene Mutation in Post-Transplantation Lymphoproliferative Diseases with T- and NK/T-Cell Phenotype

\begin{tabular}{|c|c|c|c|c|c|c|c|}
\hline \multirow[b]{2}{*}{ No. } & \multirow[b]{2}{*}{ Age/Sex } & \multirow[b]{2}{*}{ Histology } & \multirow[b]{2}{*}{ Primary site } & \multirow[b]{2}{*}{ Stage } & \multicolumn{3}{|c|}{ p53 } \\
\hline & & & & & Exon/codon & Nucleotide & Amino acid \\
\hline 1 & $32 / M$ & PT & Liver & III & $5 / 156$ & $\mathrm{CGC} \rightarrow \mathrm{GGC}$ & Arg $\rightarrow$ Gly \\
\hline \multirow[t]{3}{*}{2} & 40/M & PT & Small intestine & IV & $4 / 107$ & $\mathrm{TAC} \rightarrow \mathrm{TAT}$ & Tyr $\rightarrow$ Tyr \\
\hline & & & & & $6 / 196$ & $\mathrm{CGA} \rightarrow \mathrm{TGA}$ & Arg $\rightarrow$ stop \\
\hline & & & & & $8 / 273$ & $\mathrm{CGT} \rightarrow \mathrm{TGT}$ & Arg $\rightarrow$ Cys \\
\hline \multirow[t]{3}{*}{3} & $37 / M$ & PT & Cervical LN & III & $5 / 152$ & $\mathrm{CCG} \rightarrow \mathrm{CCA}$ & Pro $\rightarrow$ Pro \\
\hline & & & & & $6 / 194$ & $\mathrm{CTT} \rightarrow \mathrm{TTT}$ & Leu $\rightarrow$ Phe \\
\hline & & & & & $7 / 247$ & $\mathrm{AAC} \rightarrow \mathrm{GAC}$ & Asn $\rightarrow$ Asp \\
\hline \multirow[t]{5}{*}{4} & $44 / \mathrm{M}$ & PT & Muscle & IV & $4 / 56$ & $\mathrm{GAA} \rightarrow \mathrm{GAG}$ & Glu $\rightarrow$ Glu \\
\hline & & & & & $4 / 107$ & $\mathrm{TAC} \rightarrow \mathrm{TAT}$ & Tyr $\rightarrow$ Tyr \\
\hline & & & & & $5 / 176$ & $\mathrm{TGC} \rightarrow \mathrm{TAC}$ & Cys $\rightarrow$ Tyr \\
\hline & & & & & $5 / 177$ & $\mathrm{CCC} \rightarrow \mathrm{TCC}$ & Pro $\rightarrow$ Ser \\
\hline & & & & & $6 / 215$ & $\mathrm{AGT} \rightarrow \mathrm{AGC}$ & Ser $\rightarrow$ Ser \\
\hline \multirow[t]{3}{*}{5} & $34 / \mathrm{M}$ & PT & Liver & II & $4 / 101$ & $\mathrm{AAA} \rightarrow \mathrm{AAT}$ & Lys $\rightarrow$ Asn \\
\hline & & & & & $5 / 142$ & $\mathrm{CCT} \rightarrow \mathrm{CCC}$ & Pro $\rightarrow$ Pro \\
\hline & & & & & $5 / 179$ & CAT $\rightarrow$ CGT & $\mathrm{His} \rightarrow \mathrm{Arg}$ \\
\hline 6 & $32 / M$ & ATL & Undetermined & IV & - & - & - \\
\hline 7 & $32 / M$ & ATL & Inguinal LN & III & $4 / 84$ & $\mathrm{GCC} \rightarrow \mathrm{GCT}$ & Ala $\rightarrow$ Ala \\
\hline \multirow[t]{2}{*}{8} & 43/M & ATL & Skin & I & $5 / 175$ & $\mathrm{CGC} \rightarrow \mathrm{CAC}$ & $\mathrm{Arg} \rightarrow \mathrm{His}$ \\
\hline & & & & & $8 / 269$ & $\mathrm{AGC} \rightarrow \mathrm{AAC}$ & Ser $\rightarrow$ Asn \\
\hline \multirow[t]{2}{*}{9} & $56 / M$ & ATL & Spleen & IV & $4 / 84$ & $\mathrm{GCC} \rightarrow \mathrm{GTC}$ & $\mathrm{Ala} \rightarrow$ Val \\
\hline & & & & & $5 / 179$ & $\mathrm{CAT} \rightarrow \mathrm{CGT}$ & $\mathrm{His} \rightarrow \mathrm{Arg}$ \\
\hline 10 & $47 / \mathrm{F}$ & ATL & Undetermined & I & - & - & - \\
\hline \multirow[t]{4}{*}{11} & $27 / \mathrm{M}$ & Nasal NKTCL & Nasal cavity & I & $5 / 140$ & $\mathrm{ACC} \rightarrow \mathrm{ACT}$ & $\mathrm{Thr} \rightarrow \mathrm{Thr}$ \\
\hline & & & & & $4 / 144$ & $\mathrm{CAG} \rightarrow \mathrm{CGG}$ & $\mathrm{Gln} \rightarrow \operatorname{Arg}$ \\
\hline & & & & & $5 / 166$ & TCA $\rightarrow$ TTA & Ser $\rightarrow$ Leu \\
\hline & & & & & $5 / 171$ & $\mathrm{GAG} \rightarrow \mathrm{AAG}$ & Glu $\rightarrow$ Lys \\
\hline 12 & $35 / \mathrm{M}$ & Nodal NKTCL & Cervical LN & III & - & - & - \\
\hline
\end{tabular}

PT, Peripheral T-cell lymphoma, not specified; ATL, Adult T-cell leukemia/lymphoma; NKTCL, NK/T-cell lymphoma.

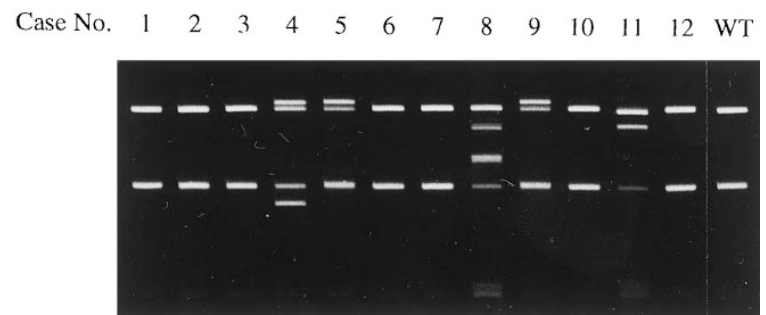

Figure 1.

"Cold" single strand conformation polymorphism analysis of p53 exon 5-a in the tissue of lymphoma developing in renal transplant patients. Aberrant migration bands compared with wild-type (WT) were seen in Cases 4, 5, 8, 9, and 11 .

Transitions at CpG dinucleotide sites were the predominant substitutions in non-Hodgkin's lymphoma (NHL) cases, and G:C to T:A transversion was uncommon (Hollstein et al, 1991). In this series of PT-LPD of T- or NK/T-cell type, 40 of 42 substitution mutations in p53, c-kit, $\beta$-catenin, and K-ras genes were transitions: $\mathrm{CpG}$ sites were involved in $20 \%$ to $30 \%$ of cases. The predominance of transition mutations in our series suggested that some "endogenous" mutagens act in lymphomagenesis. Most cases in the current series had at least one mutation that changed an amino acid, which might have provided the selection pressure for expansion. The predominant sites for p53 mutation were not presented in previous reports on NHL (Adamson et al, 1995; Ichikawa et al, 1992). In our series of PT-LPD of T- and NK/T-cell type, exons 4 and/or 5 of the p53 gene were involved in $75 \%$ of cases. Codon 179 in exon 5 was involved in two cases, but no distinct mutational "hot spots" in the p53 gene were found. Mutation at codon 825 of the $c$-kit gene found in one case of ATL was reported to be a hot spot in sinonasal NK/T-cell lymphoma (Hongyo et al, 2000).

Ras activation represents a widespread oncogenic event, and is found in $10 \%$ to $15 \%$ of human neoplasms (Barbacid, 1987). Ras (H, K, and N-ras) mutations were reported to be absent in lymphomas of immunocompetent individuals (Neri et al, 1988) and infrequent in AIDS-related lymphoma (3.7\% to 11.1\%) (Ballerini et al, 1993). Thyroid lymphoma, a lymphoma that develops in autoimmune thyroiditis, showed relatively frequent mutations in the K-ras gene (25\% of cases) (Takakuwa et al, 2000). K-ras mutation was reported in cancers in renal transplant patients who received immunosuppressive agents (Arakawa et al, 1990). Thus, we examined K-ras mutations in T- and NK/T-cell lymphomas in patients receiving renal transplantation. Twenty-five percent of T- and NK/T- cell lymphomas in our cases showed K-ras mutations, a proportion that was similar to that in thyroid lympho- 


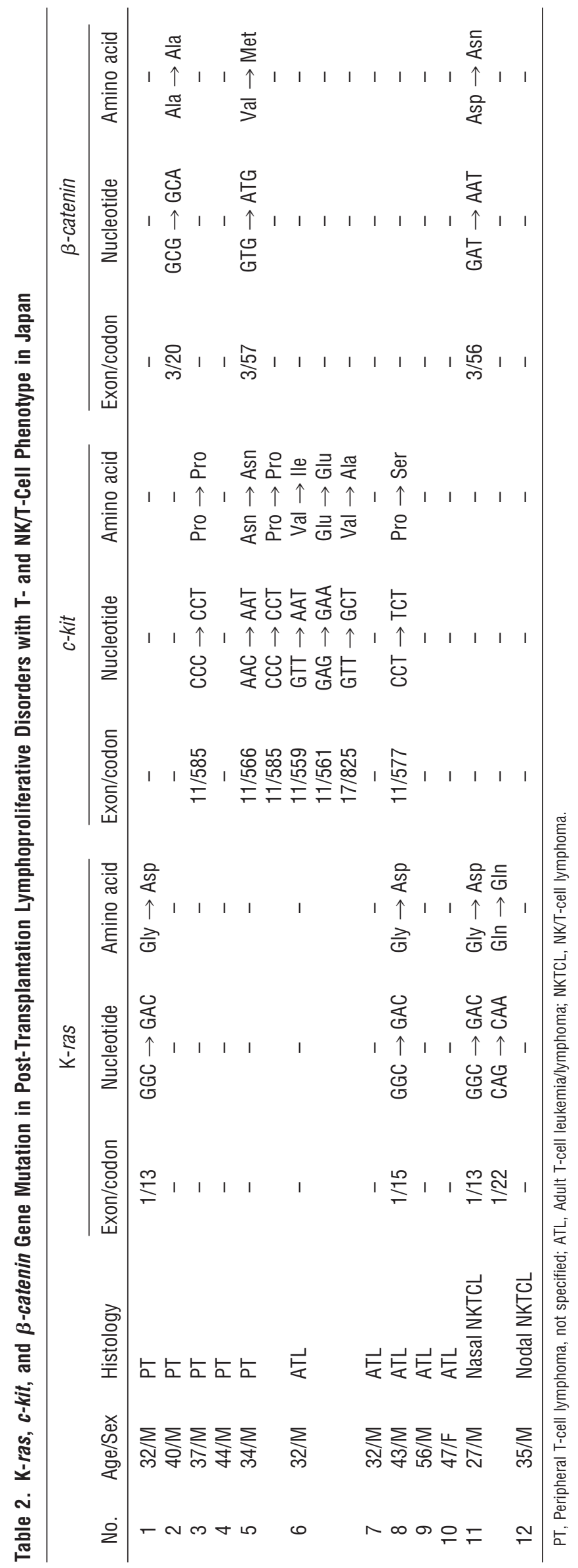


mas. Knowles et al (1995) reported that N-ras was the only ras gene altered and that $75 \%$ of monomorphic PT-LPD of B-cell type had N-ras gene mutations.

Seven mutations in the c-kit gene were found in our cases: four were missense and three were silent. Mutations in the $\beta$-catenin gene were occasionally seen in cancer of the colon (16\%) (Sparks et al, 1998), endometrium (13.2\%) (Fukuchi et al, 1998), prostate (4.8\%) (Voeller et al, 1998), and liver (13.1\%) (Hsu et al, 2000). Mutations usually involved the serine/threonine residues of the GSK- $3 \beta$ region of $\beta$-catenin. In our cases, three mutations were detected, but none of the mutations involved serine/threonine residues.

In conclusion, the present study suggested that mutations of the p53 gene are key phenomena for development of peripheral T-cell lymphoma including ATL in renal transplantation patients.

\section{Patients and Methods}

\section{Patient Characteristics}

Twelve patients in whom T-cell and NK/T-cell lymphoproliferative disorders developed after renal transplantation were selected for the present study: two patients through a review of the records of renal transplantation during the period from 1970 to 1995 at three hospitals in Japan (Osaka University Hospital, Hyogo Prefectural Nishinomiya Hospital, and Kinki University Hospital), six patients through a review of Japanese journals, three patients through the "Annual of Pathological Autopsy Cases in Japan (1977-1993)," and one patient through consultation case files of our department. Histologic specimens obtained by biopsy or autopsy were fixed in $10 \%$ formalin and routinely processed for paraffin-embedding. Histologic sections $4 \mu \mathrm{m}$ thick were stained with hematoxylin and eosin and immunoperoxidase (ABC method) as previously described (Hsu et al, 1981). Cases were classified according to the revised European American Lymphoma (REAL) classification (Harris et al, 1994), and five patients (Cases 1 through 5) were categorized as having peripheral T-cell lymphoma, not specified $\left(\mathrm{CD}_{20}^{-}, \mathrm{CD}^{-}{ }^{-}, \mathrm{CD} 3 \epsilon^{+}, \mathrm{CD} 4 \mathrm{RO}^{+}, \mathrm{CD}^{+}, \mathrm{CD}^{+}\right.$, and/or $\mathrm{TIA}-1^{+}$). Tumor cells in four of these five cases were positive for $\beta-\mathrm{F} 1^{+}$, which is known to be reactive with TCR $\beta$ chain. Another five cases (Cases 6 through 10) were categorized as ATL with proven HTLV-1 genome in the tumor tissue and seropositivity for the virus. Four of these patients (Cases 7 through 10) were born in ATL-endemic area in Japan, and presented with skin eruption typical for ATL in two patients. The remaining patient (Case 6) showed a leukemic blood picture with ATL cells occupying $48 \%$ of peripheral leukocytes. Tumor cells in these five cases were similar to those in cases with peripheral T-cell lymphomas, except for CD 56 positive in one of the ATL cases. The remaining two cases (Cases 11 and 12) with a polymorphous pattern of proliferation consisting of medium to large cells with irregular nuclei and macrophages were categorized as NK/T-cell lymphoma because the proliferating cells were $\mathrm{CD}_{16}{ }^{+}$,
$\mathrm{CD}_{6}{ }^{+}, \mathrm{CD} \epsilon^{+}, \mathrm{CD}^{-}, \mathrm{CD}^{+}{ }^{+}$or $-, \mathrm{CD}^{-} 0^{-}, \mathrm{TIA}^{-} 1^{+}$. One of NK/T-cell lymphomas arose in the nasal cavity and one arose in the lymph node. Rearrangements of the T-cell receptor $\beta$ - and $\gamma$-chain genes were examined in one case of nasal NK/T-cell lymphoma, showing the germline configuration. This case was negative for $\beta-\mathrm{F} 1$ by immunohistochemistry. Details of clinical and histologic information of these cases were reported previously (Hoshida et al, 2001). Briefly, the age of patients at the time of transplantation ranged from 17 to 47 (median, 30) years and that at diagnosis of PT-LPD ranged from 27 to 56 (median, 36) years. The interval between renal transplantation and tumor development ranged from 1 to 264 (median, 64) months. All patients, except one, were male. The primary site of PT-LPD was extranodal in seven cases, nodal in three, and undetermined in two. The Ann Arbor staging scheme was applied in all cases on the basis of physical examination records, surgical notes, and pathologic examination of the specimens: three patients had Stage I, one Stage II, four Stage III, and four Stage IV disease.

\section{Detection of $\mathrm{p} 53, \mathrm{~K}$-ras, c-kit, and $\beta$-catenin Gene Mutations}

DNA for PCR amplification was extracted using chelating resin (Sigma Chemical, St. Louis, Missouri). Briefly, three paraffin sections $10 \mu \mathrm{m}$ thick were cut, transferred into sterile distilled water containing $20 \%$ chelating resin, and boiled for 15 minutes. After centrifugation, the supernatant was transferred to a sterile $500-\mu l$ tube and stored at $-20^{\circ} \mathrm{C}$. The PCR primer pairs for amplification of exon 4 through 8 of the p53 gene, exon 1 and 2 of K-ras gene, exon 11 and 17 of $c$-kit gene, and exon 3 of $\beta$-catenin gene are listed in Table 3. DNA amplification and nonradioactive SSCP (cold SSCP) analysis were carried out to detect mutations, as described previously (Hongyo et al, 1993). Briefly, hot start PCR for DNA amplification was performed as follows: 45 cycles of denaturation at $95^{\circ} \mathrm{C}$ for 30 seconds; annealing at each temperature shown in Table 3 for 30 seconds; extension at $72^{\circ} \mathrm{C}$ for 1 minute, and final extension at $72^{\circ} \mathrm{C}$ for 7 minutes. Paraffin blocks containing no sample were cut and used as negative controls throughout the procedures. The amplified products were subjected to electrophoresis in $1.5 \%$ agarose gels containing $2 \mu \mathrm{g} / \mathrm{ml}$ ethidium bromide in TBE buffer (90 mM Tris, $92 \mathrm{~mm}$ boric acid, $2.5 \mathrm{~mm}$ EDTA). After electrophoresis, the gels were examined on an ultraviolet transilluminator.

Nonradioactive SSCP was performed as follows. Reaction mixtures consisting of $20 \mathrm{ml}$ containing $5 \mu \mathrm{l}$ of PCR product (20-200 ng of DNA), $0.2 \mu \mathrm{l}$ of $1 \mathrm{M}$ methylmercury hydroxide, $3 \mu$ l of loading buffer (15\% Ficoll, $0.25 \%$ bromphenol blue, $0.25 \%$ xylene cyanol), and TBE buffer were heated to $90^{\circ} \mathrm{C}$ for 4 minutes, put on ice, and then subjected to electrophoresis in $18 \%$ polyacrylamide TBE gels at 300 volts, while maintaining the temperatures at those shown in Table 3. The bands that migrated apart from that of wildtype were determined as SSCP-positive. The bands 
Table 3. Oligonucleotide Primers Used for PCR

\begin{tabular}{|c|c|c|c|c|}
\hline Gene & Sequences & & $\begin{array}{l}\text { Annealing temperature } \\
\text { for DNA amplification }\end{array}$ & $\begin{array}{l}\text { Maintaining temperature } \\
\text { for PCR-SSCP }\end{array}$ \\
\hline \multicolumn{5}{|l|}{ p53 } \\
\hline \multirow[t]{2}{*}{ Exon $4 \mathrm{a}$} & 5'-TTTTCACCCATCTACAGTCC-3' & Upstream & $58^{\circ} \mathrm{C}$ & $20^{\circ} \mathrm{C}$ \\
\hline & $5^{\prime}-$ CAAGAAGCCCAGACGGAAAC-3' & Downstream & & \\
\hline \multirow[t]{2}{*}{$\mathrm{b}$} & 5'-CCTGGCCCCTGTCATCTTCT-3' & Upstream & $58^{\circ} \mathrm{C}$ & $20^{\circ} \mathrm{C}$ \\
\hline & 5'-AAGAAATGCAGGGGGATACG-3' & Downstream & & \\
\hline \multirow[t]{2}{*}{ Exon $5 a$} & 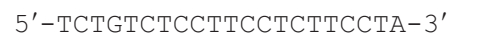 & Upstream & $57^{\circ} \mathrm{C}$ & $35^{\circ} \mathrm{C}$ \\
\hline & 5'-CATGTGCTGTGACTGCTTGT-3' & Downstream & & \\
\hline \multirow[t]{2}{*}{$b$} & 5'-TGTGCAGCTGTGGGTTGATTC-3' & Upstream & $62^{\circ} \mathrm{C}$ & $25^{\circ} \mathrm{C}$ \\
\hline & 5'-CAGCCCTGTCGTCTCTCCAG-3' & Downstream & & \\
\hline \multirow[t]{2}{*}{ Exon 6} & 5'-TTGCTCTTAGGTCTGGCCCCT-3' & Upstream & $64^{\circ} \mathrm{C}$ & $35^{\circ} \mathrm{C}$ \\
\hline & 5'-TAGGGAGGTCAAATAAGCAG-3' & Downstream & & \\
\hline \multirow[t]{2}{*}{ Exon 7} & 5'-TAGGTTGGCTCTGACTGTACC-3' & Upstream & $60^{\circ} \mathrm{C}$ & $25^{\circ} \mathrm{C}$ \\
\hline & 5'-TGACCTGGAGTCTTCAGTGT-3' & Downstream & & \\
\hline \multirow[t]{2}{*}{ Exon 8} & 5'-тстTGCTTCTCTTTTCCTAT-3' & Upstream & $56^{\circ} \mathrm{C}$ & $10^{\circ} \mathrm{C}$ \\
\hline & 5'-CGCTTCTTGTCCTGCTTGCT-3' & Downstream & & \\
\hline \multicolumn{5}{|c|}{ 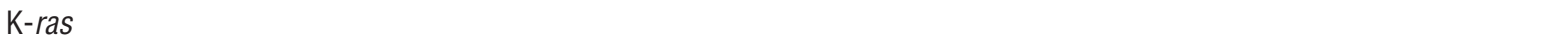 } \\
\hline \multirow[t]{2}{*}{ Exon 1} & 5'-CATGTTCTAATATAGTCACA-3' & Upstream & $48^{\circ} \mathrm{C}$ & $25^{\circ} \mathrm{C}$ \\
\hline & $\begin{array}{l}\text { 5'-CTCTATTGTTGGATCATATTCGTCC- } \\
3^{\prime}\end{array}$ & Downstream & & \\
\hline \multirow[t]{2}{*}{ Exon 2} & 5'-АСтGTGTTTCTCCCTTCTCA-3' & Upstream & $48^{\circ} \mathrm{C}$ & $5^{\circ} \mathrm{C}$ \\
\hline & 5'-CACAAAGAAAGCCCTCCCCA-3' & Downstream & & \\
\hline \multicolumn{5}{|c|}{ 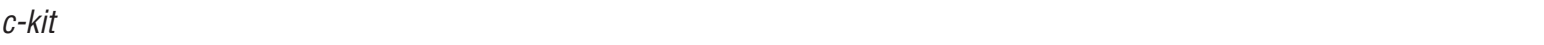 } \\
\hline \multirow[t]{2}{*}{ Exon 11} & 5'-GATCTATTTTTCCCTTTCTC-3' & Upstream & $56^{\circ} \mathrm{C}$ & $20^{\circ} \mathrm{C}$ \\
\hline & 5'-AGCCCCTGTTTCATACTGAC-3' & Downstream & & \\
\hline \multirow[t]{2}{*}{ Exon 17} & $5^{\prime}$-CATGGTCGGATCACAAAGAT-3' & Upstream & $54^{\circ} \mathrm{C}$ & $15^{\circ} \mathrm{C}$ \\
\hline & 5'-ATTATGAAAGTCACGGAAAC-3' & Downstream & & \\
\hline \multicolumn{5}{|l|}{$\beta$-catenin } \\
\hline \multirow[t]{2}{*}{ Exon 3} & 5'-GCTGATTTGATGGAGTTGGA-3' & Upstream & $56^{\circ} \mathrm{C}$ & $25^{\circ} \mathrm{C}$ \\
\hline & 5'-GCTACTTGTTCTTGAGTGAA-3' & Downstream & & \\
\hline
\end{tabular}

determined as possibly mutated by SSCP were extracted from the gels and amplified by 25 cycles of PCR to enrich the mutated alleles.

Sequencing was performed by the dideoxy chain termination method using a Big Dye terminator cycle sequencing kit (Perkin-Elmer, Foster City, California). Sequencing primers were the same as those used for PCR. Sequencing was performed according to the manufacturer's protocol: 30 cycles of denaturation $\left(95^{\circ} \mathrm{C}\right.$ for 30 seconds), annealing (54 ${ }^{\circ} \mathrm{C}$ for $30 \mathrm{sec}-$ onds), and extension ( $72^{\circ} \mathrm{C}$ for 3 minutes), and then cooling at $20^{\circ} \mathrm{C}$ after the final cycle. After ethanol precipitation, the samples were analyzed using an $A B I$ PRISM 310 Genetic Analyzer (Perkin-Elmer). PCRSSCP analyses and sequencing of mutated bands were repeated three times for each sample to exclude the possibility of contamination and PCR fidelity artefacts.

\section{Acknowledgements}

The authors thank the following pathologists and physicians for providing clinical information: Drs. A. Mukai (Tsukuba University), K. Hamaguchi (Sakura National Hospital), T. Wakabayashi, A. Masunaga (Tokyo University), K. Ohnishi, K. Miura (Hamamatsu Medical School), S. Nakamura (Aichi Cancer Hospital),
N. Mori (Nagoya University), K. Kitagawa, H. Yasoshima, A. Kubota, K. Uematsu (Hyogo College of Medicine), Y. Ichikawa, T. Kohro (Hyogo Prefectural Nishinomiya Hospital), H. Ushio (Ushio Clinic), T. Okabayashi, T. Horimi, Y. Azuma, K. Iwata (Kochi Prefectural Hospital), T. Kasai, H. Hashimoto (University of Occupational and Environmental Health), C. Yasunaga, K. Yamamoto (Saiseikai Yahata Hospital), T. Hayashi (Miyazaki Prefectural Hospital), H. Yoshida (Kagoshima University), and S. Kojya (Ryukyu University) and Mr. Y. Kabutomori for technical assistance.

\section{References}

Aberle H, Bauer A, Stappert J, Kispert A, and Kemler R (1997). $\beta$-catenin is a target for the ubiquitin-proteosome pathway. EMBO J 16:3797-3804.

Adamson DJA, Thompson WD, Dawson AA, Bennett B, and Haites NE (1995). p53 mutation and expression in lymphoma. Br J Cancer 72:150-154.

Arakawa K, Yoshida T, Nakajima H, Yasumura T, Imanishi J, and Oka T (1990). K-ras mutation in human carcinoma after kidney transplantation. Transplantation 49:213-215.

Ballerini P, Gaidano G, Gong JZ, Tassi V, Saglio G, Knowles $\mathrm{DM}$, and Dalla-Favera R (1993). Multiple genetic lesions in 
acquired immunodeficiency syndrome-related nonHodgkin's lymphoma. Blood 81:166-176.

Barbacid M (1987). Ras gene. Annu Rev Biochem 56:779827.

Behrens J, von Kries JP, Kuhl M, Bruhn L, Wedlich D, Grosschedl R, and Birchmeier W (1996). Functional interactions of $\beta$-catenin with the transcription factor LEF-1. Nature 382:638-642.

Brentnall TA, Chen R, Lee JG, Kimmey MB, Bronner MP, Haggilt RC, Krowdley KV, Hecker LM, and Byrd DR (1995). Microsatellite instabilitiy and K-ras mutations associated with pancreatic adenocarcinoma and pancreatitis. Cancer Res $55: 4264-4267$.

Chadburn A, Chen JM, Hsu DT, Frizzera G, Cesarman E, Garrett TJ, Mears JG, Zangwill SD, Addonizio LJ, Michler RE, and Knowles DM (1998). The morphologic and molecular genetic categories of posttransplantation lymphoproliferative disorders are clinically relevant. Cancer 82:1978-1987.

Dockrell DH, Stricker JG, and Paya CV (1998). Epstein-Barr virus-induced $\mathrm{T}$ cell lymphoma in solid organ transplant recipients. Clin Infect Dis 26:180-182.

Donehower LA, Harrey M, Slagle BL, McArthur MJ, Montgomery CA Jr, Butel J, and Bradly A (1992). Mice deficient for p53 are developmentally normal but susceptible to spontaneous tumors. Nature 356:215-221.

Edwards RH and Raab-Traub N (1994). Alterations of the p53 gene in Epstein-Barr virus-associated immunodeficiencyrelated lymphoma. J Virol 68:1309-1315.

Fukuchi T, Sakamoto M, Tsuda H, Maruyama K, Nozawa S, and Hirohashi $S$ (1998). $\beta$-catenin mutation in carcinoma of the uterine endometrium. Cancer Res 58:3526-3528.

Gaidano G, Carbone A, and Dalla-Favera R (1998). Genetic basis of acquired immunodeficiency syndrome-related lymphomagenesis. J Natl Cancer Inst Monogr 23:95-100.

Harris NL, Ferry JA, and Swerdlow SH (1997). Posttransplant lymphoproliferative disorders: Summary of society for hematopathology workshop. Semin Diagn Pathol 14:8-14.

Harris NL, Jaffe ES, Stein H, Banks PM, Chan JKC, Cleary ML, Delsol G, Wolf-Peeters CD, Falini B, Gatter KC, Grogan TM, Isaacson PG, Knowles DM, Mason DY, Muller-Hermelink HK, Pileri SA, Piris MA, Ralfkiaer E, and Warnke RA (1994). A revised European-American classification of lymphoid neoplasms: A proposal from the International Lymphoma Study Group. Blood 84:1361-1392.

He TC, Sparks AB, Rago C, Hermeking H, Zawel L, da Costa LT, Morin PJ, Vogelstein B, and Kinzler KW (1998). Identification of c-myc as a target of the APC pathway. Science 281:1509-1512.

Hollstein M, Sidransky D, Vogelstein B, and Harris SR (1991). p53 mutations in human cancers. Science 253:49-53.

Hongyo T, Buzard GS, Calvert RJ, and Weghorst CM (1993). 'Cold SSCP': A simple, rapid and non-radioactive method for optimized single strand conformation polymorphism analyses. Nucleic Acids Res 21:3637-3642.

Hongyo T, Li T, Syaifudin M, Baskar R, Ikeda H, Kanakura Y, Aozasa K, and Nomura T (2000). Specific c-kit mutations in sinonasal natural killer/T-cell lymphoma in China and Japan. Cancer Res 60:2345-2347.
Hoshida Y, Li T, Dong Z, Tomita Y, Yamauchi A, Hanai J, and Aozasa K (2001). Lymphoproliferative disorders in renal transplant patients in Japan. Int J Cancer 91:869-875.

Hsu H-C, Jeng Y-M, Mao T-L, Chu J-S, Lai P-L, and Peng S-Y (2000). $\beta$-catenin mutations are associated with a subset of low-stage hepatocellular carcinoma negative for hepatitis $\mathrm{B}$ virus and with favorable prognosis. Am J Pathol 157:763770.

Hsu S-M, Raine L, and Fanger H (1981). The use of antiavidin antibody and avidin-biotin-peroxidase complex in immunoperoxidase technics. Am J Clin Pathol 75:816-821.

Huber O, Bierkamp C, and Kemler R (1996). Cadherins and catenins in development. Curr Opin Cell Biol 8:685-691.

Ichikawa A, Hotta T, Takagi N, Tsushita K, Kinoshita T, Nagai H, Murakami Y, Hayashi K, and Saito H (1992). Mutations of p53 gene and their relation to disease progression in B-cell lymphoma. Blood 79:2701-2707.

Imamura J, Miyoshi I, and Koeffler HP (1994). p53 in hematologic malignancies. Blood 84:2412-2421.

Jackson JH, Vollenweider $\mathrm{M}$, Hill J, Rodriguez $\mathrm{H}$, Schnabacher AW, Mitra G, and Kuo CT (1997). Stimulated human leukocytes cause activating mutations in the K-ras protooncogene. Oncogene 14:2803-2808.

Kitayama H, Tsujimura T, Matsumura I, Oritani K, Ikeda $\mathrm{H}$, Ishikawa J, Okabe M, Suzuki M, Yamamura K, Matsuzawa Y, and Kanakura $Y$ (1996). Neoplastic trasformation of normal hematopoietic cells by constitutively activating mutations of c-kit receptor tyrosine kinase. Blood 88:995-1004.

Knowles DM, Cesarman E, Chadburn A, Frizzera G, Chen J, Rose EA, and Michler RE (1995). Correlative morphologic and molecular genetic analysis demonstrates three distinct categories of posttransplantation lymphoproliferative disorders. Blood 85:552-565.

Leblond V, Sutton L, Dorent R, Davi F, Bitker MO, Gabarre J, Charlotte F, Ghoussoub JJ, Fourcade C, Fischer A, Gandjbakhch I, Binet JL, and Raphael M (1995). Lymphoproliferative disorders after organ transplantation: A report of 24 cases observed in a single center. J Clin Oncol 13:961-968.

Levine AJ, Momand J, and Finley CA (1991). The p53 tumor suppressor gene. Nature 351:453-456.

Li T, Hongyo T, Syaifudin M, Nomura T, Dong Z, Shingu N, Kojya S, Nakatsuka S, and Aozasa K (2000). Mutations of the p53 gene in nasal NK/T-cell lymphoma. Lab Invest 80:493499 .

Morin PJ, Sparks AB, Korinek V, Barker N, Clevers $H$, Vogelstein B, and Kinzler KW (1997). Activation of $\beta$-catenin -Tcf signaling in colon cancer by mutations in $\beta$-catenin or APC. Science 275:1787-1790.

Nalesnik MA (1998). Clinical and pathological features of post-transplant lymphoproliferative disorders (PTLD). Semin Immunopathol 20:325-342.

Neri A, Knowles DM, Greco A, McCormick F, and DallaFavera R (1988). Analysis of ras oncogene mutations in human lymphoid malignancies. Proc Natl Acad Sci USA 85:9268-9272.

Pen I, Hammon W, Brettschneider L, and Starzl TE (1969). Malignant lymphoma in transplantation patients. Transplant Proc 1:106-112. 
Sparks AB, Morin PJ, Vogelstein B, and Kinzler KW (1998). Mutational analysis of the APC/ $\beta$-catenin/Tcf pathway in colorectal cancer. Cancer Res 58:1130-1134.

Starzl TE, Nalesnik MA, Porter KA, Ho M, Iwatsuki S, Griffith BP, Rosenthal JT, Hakala TR, Shaw BW Jr, Hardesty RL, Atchinson RW, Jaffe R, and Bahnson HT (1984). Reversibility of lymphomas and lymphoproliferative lesions developing under cyclosporine-steroid therapy. Lancet 1:583-587.
Takakuwa T, Hongyo T, Syaifudin M, Kanno H, Matzuzuka F, Narabayashi I, Nomura T, and Aozasa K (2000). Microsatellite instability and K-ras, p53 mutations in thyroid lymphoma. Jpn J Cancer Res 91:280-286.

Voeller HJ, Truica Cl, and Gelmann EP (1998). $\beta$-catenin mutations in human prostate cancer. Cancer Res 58:25202523. 